\title{
Armed Non-State Actors and State Failure: Failing International Law or Failure of International Law
}

\author{
SULEIMAN USMAN SANTURAKI
}

\begin{abstract}
Armed Non-State actors are groups involved in the use of force against states or within themselves under several guises including the right to self-determination. The activities of such groups have over the years led to the failure of several states across the globe, which on the other hand results in dire human and material consequences. As a result, the question has often been asked as to why such armed non-state actors thrive especially in the $21^{\text {st }}$ century, notwithstanding the prominence of international law. Is it that international law has failed in regulating such groups, or that the regulation has in it some inherent weaknesses which encourage their proliferation. This paper examines the role of non-state actors in state failure with reference to a few selected cases, to see how activities presented as emancipatory lead to human devastation. It also explores the international legal regime on non-state actors with a view to see if it encourages the emergence of violent groups in the form of national liberation movements. Using doctrinal methodology, the paper analyses both primary and secondary sources of data, relevant literature, and case law on the topic. It finds that the proliferation of the activities of these groups who destroy the essence of statehood, may not be unconnected with the contemporary reality of the legal regime in international law.
\end{abstract}

Keywords: Non-State Actors, Failed State, International Law, Use of force, National liberation movements

\section{INTRODUCTION}

The true position of armed non-state actors within the international legal sphere in relation to the prohibition against the use of force is still one of the most highly debated topics in international law. ${ }^{1}$ To add to the quandary is the emergence of National Liberation Movements (NLMs) and the right to self-determination as one of the human rights recognised by the international community. The right to selfdetermination is recognised as one of the fundamental principles upon which the UN system is built. ${ }^{2}$ Consequently, groups fighting for their right to self-determination popularly known as National Liberation Movements (NLMs) have traditionally been supported under the UN system. Hence, from 1945 when the UN Charter came into force, the number of armed nonstate actors fighting under the guise of NLMs has grown out of proportion. This is a sharp contrast to the prohibition against the use of force under the UN Charter. ${ }^{3}$ This was made possible because despite their international legal position and the wide sympathy for NLMs, their exact meaning and practical definition is still at the best, hazy. The legal framework in international law is such that support to NLMs is legally justified; they are often given exalted position in international law and recognised by some states as the legitimate representatives of their people.

This paper therefore, explores the relationship between the customary position in international law which supports the grant of recognition to belligerents and the support for NLMs from the UN, to see if the system has encouraged the use of force by these groups. It juxtaposes the practical happenings around the globe as is clearly demonstrated by a cursory look at the failure of many states leading to the outpouring of refugees globally, with the need for self-determination. The paper briefly surveys the unending crisis in Somalia, Afghanistan, Syria and, the Boko Haram violence in Nigeria, all of which have caused the displacement of millions. What they also have in common is the claim by several armed groups responsible for the crises that they are fighting to liberate their people. This being the case, 
the paper poses the question if the international regulation of armed non-state actors is a true validation of the peoples' right to self-determination. It tries to find if the blame is on the substance of the law or a failure to implement the law.

\section{NON-STATE ACTORS}

The term 'non-state actors' is used generally with reference to groups or organisations having international relevance and influence though they are not directly connected to sovereign states. The terminology is itself confusing if not contradictory as it is used to define or identify groups whose aims, and objectives are the extreme opposites. Hence, non-state actors may be used with reference to international civil society organisations or non-governmental organisations whose objectives are primarily civil and lifesaving or life-promoting. Used within this context, groups struggling to protect or promote human rights, freedom, education, health care, the environment and other noble causes fall within the broad definition of non-state actors. ${ }^{4}$ Likewise, the term denotes violent armed groups which have come to dominate the international scene using violence against states and other non-state entities to achieve their aims, most of which are political. This second classification is also referred to as armed non-state actors or organised armed groups; ${ }^{5}$ they constitute the focal point of this paper. Violent or organised armed groups are non-state actors that are involved in the use of force in diverse methods to pursue the achievement of their political or economic objectives.

Though these groups may be as powerful as, or more powerful than some states, they are generally not recognised as subjects of international law in the strict legal sense. ${ }^{6}$ Non-state actors are designated as such because of the understanding that they bear no political, physical or fiscal allegiance to any particular state and are deficient of formal state structure. ${ }^{7}$ Indeed, they are autonomous from the governments of sovereign states notwithstanding any informal sympathy or support that may exist. Non-state actors, be they CSOs or organised armed groups, have emerged as powerful and relevant actors on the international scene. The impact of the activities of armed non-state actors has led to calls for their legal recognition as subjects of international law; at least to make them accountable for their actions. ${ }^{8}$

\section{FAILED STATE}

The concept of 'failed state' or 'state failure' though not new, is relatively obscure as it is cloaked in academic discourses that seem not to have converged on a common definition. For a start, while the term 'failed state' is popularly used across disciplines, other terms are also known to be used about relatively the same situation. For instance, terms such as 'fragile states', 'weak states', and 'failing states,' are also commonly used to describe such states which are otherwise recognized as having failed. But then, at what point a state is deemed to have failed is an issue not clearly determined in international law. It is true that international law recognizes certain basic features of statehood such as territory, government, population, and the capacity to enter relationship with other states. ${ }^{10}$ Leaving the debates on the veracity of these attributes aside, one would find that neither writers nor states agree on what the exact connotations of either of these attributes are. Hence, how to define a state territory for instance is not a matter clearly settled in law; same goes for all the other elements.

However, if these elements constitute the fundamental requirements for statehood in international law, does it follow thereby that deficiency or the absence of any of them automatically results in state failure? Obviously, 
contemporary international law gives no credence to such a position. The provision of Article 1 of the Montevideo Convention though not universally accepted as the position of the law, has always been cited as the basis for academic discourses on statehood. ${ }^{11}$ Nevertheless, the requirements of the Convention were primarily stated as proposed standards for evaluating the formation of states; certainly, not as conditions for measuring the continuance of states. Be that as it may, it is highly complex to determine whether the formation of a new state is a matter of law or that of fact. This indeterminacy led to the principle of effectiveness as the most important element in determining statehood. $^{12}$

Consequently, most of the indexes of state failure available today are not so much concerned with the existence of any of the four elements mentioned above. In most cases, they tend to concentrate on what they consider the attributes of an effective state. It is therefore common to see references being made to deeply conflicted, dangerous, or tense states. ${ }^{13}$ In most cases, there is so much emphasis on the ability of the state or government to provide the necessities of life such as security, peace, and other civil needs. ${ }^{14}$ Whether a state is considered as having failed or not will therefore, to a large extent depend on what criterion one uses to evaluate state failure. ${ }^{15}$ So much that different institutions or bodies may arrive at different positions in relation to whether a state has failed or not. ${ }^{16}$ The debates notwithstanding, one may arrive at certain basic elements or features intrinsic in all discussions of a failed state. Thus, it is common that state failure is characterised by some of these elements: absence or dire deficiency of social infrastructure such as health care, education, justice delivery, transportation, and a weak economy resulting into diminishing GDP per capita. ${ }^{17}$ It is also common to find that such a state is rife with crime and violence, be it ethnic, political, or religious, to make life difficult or unbearable. ${ }^{18}$

The criteria for the determination of state failure are not sacrosanct, nor are they fixed by the people living in such states; consequently, it is difficult to decide whether a state has failed by mere theoretical analysis. This is more the case when such analysis is being made from without such states deprived of input from the people living therein. Notwithstanding, it may be concluded that where such people living in that territory begin to flee the comfort of their homes and their comfort zones, then the institution of statehood has failed. People do not find it easy to abandon their homes and the means of livelihood they are used to; when they do that, then something is fundamentally wrong. One can assume that the essence of that place being called home has been taken away. Within the context of this paper therefore, a state is considered as having failed if it is unable to meet the basic social requirements expected of it by its citizens. These may include, though is not limited to peace, security and social infrastructure. State failure in this context is therefore seen more as a process culminating in deterioration of the state's capability to meet up to its responsibilities to its citizens and its inability to protect its citizens from genocide, crime against humanity, war crime and ethnic cleansing.. And within this context, such a failure is because of the violent activities of nonstate actors either against one another or against the state as an institution.

\section{THE ACTIVITIES OF NON-STATE ACTORS AND STATE FAILURE}

Armed non-state actors in the form of national liberation movements, rebels or insurgents, and terrorist organisations have been responsible for the failure of many states especially in the developing world. This trend has become more pronounced and pressing in African and middle-eastern states over the past three decades. In some 
of these countries, governance and the essence of statehood has been brought to a standstill or to the barest minimum. As may be seen with respect to the selected states below, the activities of armed nonstate actors have brought these states to their knees, practically drawing them into the fold of failed states. Essentially, because of the violence perpetrated by these groups, the institution of governance in these states has been brought to a halt. Consequently, since the essence of government is to provide security for the population, where such cannot be guaranteed, in addition to diminished or outright absence of infrastructure, the state might well be deemed to have failed.

\section{SOMALIA}

Somalia is one of the countries with many of its citizens displaced as refugees in several states across the globe. ${ }^{19}$ The political crisis in Somalia might have had its roots in the 1977 regime change that altered the political structure of the country. Although it had witnessed three major armed conflicts between 1977 and $1991,{ }^{20}$ the level of devastation got worse in the years that ensued thereafter. There are several factors responsible for the destruction and insecurity in Somalia, chief among them is the involvement of nonstate actors in the form of NLMs using force. From the formation of the Somali Salvation Democratic Front (SSDF) in 1978, the Somali National Movement (SNM) in 1981, the United Somali Congress, USC, the Somali Patriotic Movement, and the Somali Salvation Democratic Movement in the early $1990 \mathrm{~s},{ }^{21}$ the security situation has only deteriorated. Others include the Al-Itihaad al-Islamiya (AIAI) 1983, the Islamic Courts Union (ICU), and Al Shabaab in $2005 .^{22}$ With more violent non-state actors emerging in the 1980s and 1990s, the situation intensified with the violence that followed leading to famine, death, and devastation. Hence, the emergence of these armed groups and their involvement in the use of force cannot be divorced from the devastation in Somalia. This has led to destruction of lives, property, and public infrastructure; insecurity and near state of anarchy. This situation is responsible for the emergence of Somalia as one of the most classic examples of a failed state in contemporary discourse. $^{23}$

\section{THE BOKO HARAM VIOLENCE IN NIGERIA}

The emergence of the Boko Haram sect and the ensuing conflict between the sect and government forces has had devastating impact on some parts of the country and its population. Most of the destructions and devastations faced were caused by the Boko Haram fighters and in some instances government troops in response to attacks by the group. ${ }^{24}$ The Boko Haram group also emerged initially as freedom fighters brandishing ideals meant to emancipate the people from injustice and oppression. The war progressively trickled into nearby nations, with amplified permeation, attacks, recruitment, and suicide-bombings by the armed group, provoking the movements of people from the conflict zone in Nigeria across borders to Chad, Cameroon, and Niger. ${ }^{25}$ The activities of the Boko Haram armed group has led to the destruction of private property and public infrastructure in the North-eastern part of Nigeria on a scale never witnessed before. ${ }^{26}$ In some cases, entire townships have been annihilated while putting pressure on limited infrastructure in others as a result of the influx of displaced persons. ${ }^{27}$ The result is a near failure of the institution of statehood especially between the years 2011-2016. The eruption of the Boko Haram rebellion has increasingly turned into the sole reason for displacement in the area. It has resulted in the displacement of no less than 2.3 million persons either as refugees, or internally displaced people (IDPs). ${ }^{28}$ 


\section{AFGHANISTAN}

The crisis in Afghanistan which has also led to mayhem and the destruction of lives, property and public infrastructure has a long and complex history. ${ }^{29}$ It is true that such factors as colonial British influence, deepening ethnic, religious, and sectarian differences had their impact on the system. ${ }^{30}$ However, the destruction that led to consistent insecurity and diminished social infrastructure has its immediate roots in the activities of armed non-state actors in the state. This can be traced back to the 1920's with the early emergence of such ethnic and religious groups opposing the attempts at westernization. ${ }^{31}$

The Russian invasion in the 1980s and the American support to several armed groups encouraged the militarisation of rural Afghanistan escalating the burgeoning violence. ${ }^{32}$ One can see a pattern like other states where these groups first rise as NLMs. The eventual emergence of the Taliban after the withdrawal of the US from the country and the events that led to the $9 / 11$ attacks and subsequent US invasion are all relatable to the activities of these armed non-state actors. Interestingly, they all emerged under the guise of NLMs or something in that nature. Hence, the gradual dwindling of infrastructure and governance in Afghanistan has a direct correlation to the activities of these armed non-state actors. ${ }^{33}$ Consequently, as the violence escalated and reached its peak with the US invasion, coupled with a near absence of the structure of governance, the state cascaded to a failed status. ${ }^{34}$ More than any of the states considered, the case of Afghanistan is more clearly related to the activities of non-state actors leading to its failure.

\section{SYRIA}

Syria has been on the international radar in terms of violence and humanitarian crisis for seven years now. Though the Syrian conflict started as a civil resistance to human rights abuses and highhandedness by government, it quickly escalated into a fully blown civil war. This conflict has so far caused the loss of more than half a million lives and destruction to both private and public property. ${ }^{35}$ The brutal response by the Syrian government was responsible for the escalation of the crisis in Syria; as the government was accused of arresting and killing of innocent citizens including children. ${ }^{36}$

However, the escalation of the Syrian conflict into a complete war has its immediate roots in the creation and organisation of the so-called opposition together with the foreign support they received. ${ }^{37}$ The Syrian opposition comprising of several armed non-state actors strengthened by financial support and weapons from foreign countries took on the Syrian government in open violent confrontation. ${ }^{38}$ To make matters worse, countries like Iran and Russia got directly involved in support of the Syrian government while the US and other western states supported the rebels. This situation gave birth to the emergence of other armed groups like Al-Qaeda and ISIS who later got involved in the devastation of the Syrian people. ${ }^{39}$ The result of this is one of the most devastating humanitarian crises witnessed since the end of World War II. So far, law and order has evaded the Syrian people; public infrastructure and private property has been destroyed to the extent that one wonders what is left of the Syrian state.

In all the states discussed above, not ignoring similar cases like Libya, South Sudan, Burundi and DRC to mention but a few, there is a clearly comparable pattern evolving across the globe. All the conflict situations are either primarily caused by armed non-state actors, or where they were not the main cause, their involvement escalates it. Almost always, these armed non-state actors take up arms in the name of protecting their states or people. Similarly, these activities certainly lead to the failure or near failure of that 
state. The question that begs for an answer is whether the international legal regime has failed to regulate the activities of armed non-state actors by whatsoever named called, or that the law as it is helps in breeding them.

\section{THE INTERNATIONAL LEGAL REGIME ON NON-STATE ACTORS}

Some of these non-state actors have been recognised players in international law for as long as the system existed; yet the legal regulation of non-state actors is still fuzzy. $^{40}$ For instance, rebels and insurgents, graduating to become belligerents have been part of the international system as it developed throughout the ages. ${ }^{41}$ Though the classification of terrorists as non-state actors might not have a long history in international law as rebels for instance, terrorism also has a long history on the international sphere. ${ }^{42}$ As for NLMs, they might initially have been subsumed under rebellion or insurgency before their days of glory starting after World War II. Contemporary reality however, shows that armed non-state actors have emerged as influential actors in international law notwithstanding their blurry legal position. This has led to calls for the recognition of their legal status as subjects of contemporary international law; that will at least bring them within the purview of the law. ${ }^{43}$ But then, the nature of international law is such that it remains state-centred in its structure and law-making process. States on the other hand are not willing to accept non-state actors as subjects of international law as that will have dicey consequences especially bearing in mind the violent and illegal activities of most of these groups. ${ }^{44}$

For rebels and insurgents, the legal position is more of a gradual movement from pure illegal activities to be dealt with under domestic law enforcement to pseudo recognition in international. All subjects taking up arms against their state were considered as rebels who may gain legal recognition once in control of territory and population, leading to recognition of belligerency. ${ }^{45}$ Thus, control over territory in addition to having a just cause transmutes a movement hitherto seen as seditious or rebellious into civil war where the law of war applies. ${ }^{46}$ At this point, the belligerents have attained a subject-like status in international law, and may be recognised by other states willing to enter legal relationship with them. The position is such that simple criminal activities may blossom into strong opposition having control over territory and capable of resisting the state structure. Once this happens, recognition of belligerency imbues them with a quasi-state status in a civil war situation. ${ }^{47}$ At this point, it is no longer an issue of domestic law enforcement against criminal elements or scuffles. Belligerents are recognised as subjects with rights to conclude treaties in customary international law; ${ }^{48}$ this favourable position of the law towards insurgency paved the way for the rise of NLMs especially after World War II. ${ }^{49}$

\section{As for National Liberation} Movements, (NLMs) the desire to gain independence by nations under colonial rule and the attempt at moral redemption by western colonialists paved the way for their favourable treatment in international law. The recognition of the rights of all peoples to self-determination under the UN Charter and the Universal Declaration of Human Rights further reinforced the position of NLMs. ${ }^{50}$ NLMs typically were identified with the fight against colonial rule though that is clearly not the only meaning given to NLMs as it is capable of fitting into any struggle for selfdetermination. ${ }^{51}$ As opposed to rebels or insurgents, though they often occupy a part of the territory they are fighting to liberate, that is not a necessary qualification as they can even be based out of the country. ${ }^{52}$ The support received by NLMs stems from the sympathy they enjoyed from former colonies and developing nations. This led 
to the exalted status they received under the UN and its agencies. Thus, the practice of the UN and its organs including the Security Council (UNSC) over the years has deemingly developed into extensive customary international law. The UNSC has granted observer status to the Palestinian Liberation Organisation (PLO) $;{ }^{53}$ just as several NLMs could take part in sessions of the UNGA and other UN specialised bodies though without voting rights. ${ }^{54}$ In certain instances such as that of the South-West Africa People's Organisation (SWAPO), NLMs were recognised by the UNGA as the authentic representative of their people. ${ }^{55}$

NLMs are accorded an edge over insurgents and rebels in international law as they are not required to have control over land as a precondition for their recognition. ${ }^{56}$ In addition, states are not precluded by law from advancing financial, military, or political support to NLMs as opposed to what obtains with respect to rebels and insurgents. In fact, support to regimes suppressive of NLMs is what the law proscribes. ${ }^{57}$ The position of NLMs is therefore, that of subjects of international law as they can maintain offices in other countries, conclude treaties with other states, and are bound by norms of international law on the conduct of warfare and treaties. ${ }^{58}$

With respect to terrorist organisations, the difficulty in agreeing to a common definition of the term "terrorist" or "terrorism" complicates the search for a universal legal framework on terrorists. Interestingly, the struggle for selfdetermination is always one of the contentious hurdles to agreement on a common definition of terrorism; though other issues such as interests of states are also factors. So that in defining terrorism, violence by NLMs has always been a point of contention as some states will insist on excluding same from any definition of terrorism. $^{59}$ As states have historically engaged in violence as they still are, the problem seems to be that of determining whose violence suits categorisation as terrorism. ${ }^{60}$ Consequently, we see some states attempting to maintain their hold on use of violence especially against vulnerable and minority groups; on the other hand, sympathetic states are also bent on allowing such groups the possibility of retaliating with similar violence. These groups normally come in the form of NLMs fighting for self-determination of their people.

Notwithstanding the difficulty in agreeing on a common definition of terrorism, there is consensus in condemning acts of terrorism globally. The illegality of terrorism is therefore not in doubt as such activities constitute crimes in international criminal law such as genocide, crimes against humanity and war crimes. Terrorist activities are also proscribed under international humanitarian law, human rights law, and customary international law. In addition, most terrorist activities are clearly violations of norms of jus cogens. ${ }^{61}$ This is in addition to the array of international legal instruments on terrorism and UNGA and UNSC resolutions on terrorism all of which help in providing direction on the legal framework. Accordingly, though a common definition may be desirable and has not been forthcoming, there is already an international consensus on the illegality of terrorist offences. The problem with the lack of a universally accepted definition however, is that several acts of violence which would otherwise have qualified as terrorism fall in the grey area. This exactly is where violent activities by self-styled NLMs by what so ever name called always find support. This is one of the shortcomings of the legal regime that has in no small measure contributed to the failure of states.

The Effect of the Legal Regime on NonState Actors on State Failure

The international legal regime on armed non-state actors seem quite favourable to the activities of armed groups. Violent groups which have been responsible for 
destruction of lives and property can transmute into an enviable position in international law simply by establishing themselves as formidable forces against a state structure. Thus this position means that they can become vital players in international law depending on how forceful and violent they can be. Therefore, all they need to do is to ensure access to as much destructive arsenals as possible and to unleash as much violence and destruction as can grant them control over territory.

The confusion in international law over who really is a terrorist has also helped in providing safe-heavens for violent groups engaged in the destruction of lives and property. This is reflected in the way groups which are essentially prone to violence and destruction end up claiming to be freedom fighters and liberation movements for the same people whose lives and livelihoods they have destroyed. A classic example is the narrative on how the US established the Al-Qaeda network and the Taliban in Afghanistan as freedom fighters supplying them with arms and finances. ${ }^{62}$ These same groups were later categorised as terrorist by the US and used as the basis for the invasion of Afghanistan. More recently, though the so called Syrian opposition was responsible for gross violation of human rights and humanitarian laws, several western countries recognised and supported it against the legitimate government in that country. ${ }^{63}$ The result was devastation and the near failure of the Syrian state.

The neutrality of the legal regime on the advent of rebellious groups for instance, enables the proliferation of armed non-state actors under the guise of NLMs across third world countries which have limited resources to tackle such challenges. And because the law allows it, other states support these groups both openly and covertly either as NLMs or belligerents. As a result, these groups continue to unleash perdition in these territories making peace and security impossible to achieve. Peace and security on the other hand are core requirements in every society howsoever developed or primeval; just as violence negates these concepts. Because peace and security are needed for the most basic development or even human existence to thrive, it is not surprising that wheresoever violence becomes the norm, peace and security are thereby diminished if not prevaricated. On the other hand, armed non-state end up destroying the very essence of the societies they initially set out to protect. This is typically identifiable in almost all cases involving armed groups. The relationship is also the other way around; where states fail, it serves as a breeding ground for armed non-state actors to thrive. ${ }^{64}$ This is so because it ostensibly becomes ungoverned territory where anything goes due to the absence of, or deficient law enforcement.

Because the uses of force by armed non-state actors seriously threaten the state monopoly of force, it tends to affect the political order and every other aspect of life in such communities. Hence, use of force by non-state actors undermine security in states and of states as it often serves as the foundation for illicit trade in drugs and weapons, illegal trades, and money laundering. ${ }^{65}$ Because the domination of the use of force by a state is an integral part of contemporary statehood, relating the political order of a state and the use of force by non-state actors is essential. Once these non-state actors veer into the state's monopoly on the use of force, it automatically creates a problem for the relevant state and its population both domestically and internationally. For the most part therefore, violent armed groups are a cause of complications for the communities they operate in. This is because the violence brought about by armed non-state actors destroy peace, security, and development; hence, where these things are found to be lacking or crucially deficient, the state would have failed. Where the state fails, it means it can 
no longer cater for the needs of people living therein. Typically, states where nonstate actors flourish end up as failed states because of the ensuing violence which leads to anarchy. It is therefore not surprising that states like Somali, Afghanistan, Syria, South Sudan, and Nigeria are constantly present within the failed state indexes developed by several organisations. ${ }^{66}$

\section{CONCLUSION}

The violence perpetrated by armed nonstate actors has caused displacement of millions of people globally despite the prohibition on the use of force in international law. These groups have somehow been able to continue to destabilize many states and populations because of their resort to violence. The failure of international law to curb the activities of armed non-state actors may be seen both from the inadequacy of the law and failure or refusal to apply the law, resulting in the favourable treatment accorded these groups. International law has over the years favoured the emergence of belligerents by according them subjectlike positions and rights once they are in control of territories and indicate a just cause. This has made it easier for all violent groups to strive by whatsoever means to acquire control over territory thereby making it possible for states to accord them recognition.

Moreover, there has also been deliberate misapplication of the law by states bent on supporting armed struggles and civil strife. This comes in the form of supporting groups involved in violent activities that have led to death and displacement of the population. The failure to agree on a universally acceptable definition of terrorism coupled with the favourable and often exalted position given to NLMs made it possible for groups to easily metamorphose into freedom fighters. It is therefore necessary that the blank cheque support given to NLMs be curtailed by placing certain criterion on recognition of such groups and provision of support to them. The international community must develop a process whereby genuine NLMs should first be identified by a special committee of the UNSC before states can deal with them or provide them support. It is true that peoples' right to self-determination should be protected and jealously guarded; however, the essence of such a right should not be lost in the process. Otherwise, what is the essence of self-determination when most of the population have either been killed or displaced? It is also necessary that a common and universally accepted definition of terrorism be arrived at in international law. This will help in filtering genuine NLMs as opposed to groups engaged in terrorism which end up destroying and displacing the population.

\section{NOTES}

1 Jordan J Paust, "Non-State Actor Participation in International Law and The Pretense of Exclusion," (2010) 51 (4) Virginia Journal of International Law, 977.

See for example, The UN Charter, article 1 (2); the International Covenant on Civil and Political Rights (ICCPR) article 1 (1); the International Covenant on Economic Social and Cultural Rights (ICESCR) article 1 (1).

3 Charter of the United Nations (San Francisco 1945)

https://treaties.un.org/doc/Publication/CTC/unc harter.pdf, art. 2 (4). (hereinafter, UN Charter).

4 Anthea Roberts and Sandesh Sivakumaran, "Lawmaking by Nonstate Actors: Engaging Armed Groups in the Creation of International Humanitarian Law," Yale J. Int'l L. 37, no. 1 (2012): 107-52, 118.

5 Robert I Rothberg, "The New Nature of NationState Failure," (2002)25 (3) The Washington Quarterly, 85-96.

6 Though this state - centric approach in international law is continuously being challenged, it remains the position. See e.g. Anna Stilz, "Decolonization and SelfDetermination," (2015) 32 (1) Social Philosophy and Policy, 1-24, doi:10.1017/S02 65052515000059, 236.

7 Weiss, Seyle, and Coolidge, "The Rise of NonState Actors in Global Governance", 142

8 Roberts and Sivakumaran, "Lawmaking by Nonstate Actors: Engaging Armed Groups in 
the Creation of International Humanitarian Law," 4.

9 See for example, Brian Dube and Proceed Manatsa, "Failed State Discourse under International Law $\square$ : The Place , Attributes and Implications," (2013) 4 (4) International Journal of Politics and Good Governanc,1-23, p. 4-6.; Michael Brent, "Responding to Attacks by Non-State Actors $\square$ : The Attribution Requirement of Self-Defence," (2009) 16 Austl. Int'l L.J., no. October, 133-59.

10 See the Organization of American States (OAS), Convention on Political Asylum, 26 December 1933, (Montevideo Convention); available at: http://www.refworld.org/docid/4f3d180a2.html [accessed 31 October 2017] article 1.

11 Annyssa Bellal, Gilles Giacca, and Stuart Casey-Maslen, "International Law and Armed Non-State Actors in Afghanistan," (2011) 93 (881) International Review of the Red Cross, 47-79.

12 Mohammad H. Zarei and Azar Safari, "The Status of Non-State Actors under the International Rule of Law: A Search for Global Justice," in Rethinking International Law and Justice, ed. Charles Sampford, Zifcak Spencer, and Aydin Okur Derya (Farnham, United Kingdom: Ashgate Publishing Ltd., 2015), 233$52,237$.

13 Ibid.

14 Janne E . Nijman, "Non-State Actors and the International Rule of Law: Revisiting the 'realist Theory' of International Legal Personality," in Non-State Actor Dynamics in International Law: From Law-Takers to LawMakers, ed. M. Noortmann and C. Ryngaert, Farnham, United Kingdom: Ashgate Publishing Limited, 2010, 91-124, 92-3.

15 Ilona Szuhai, "Rethinking the Concept of Failed State," (2015) (2) Central European Papers III, 99-110, 103.

16 Maguii Moreno Torres and Michael Anderson, "Fragile States: Defining Difficult Environments for Poverty Reduction," (2004) (1), PRDE Working Paper. http://www.ineesite.org/uploa ds/files/resources/doc_1_FS-Diff_environ_fo r_pov_reduc.pdf (Accessed 21/9/2017), 5.

17 Szuhai, "Rethinking the Concept of Failed State," 103-4.

18 Moreno Torres and Anderson, "Fragile States: Defining Difficult Environments for Poverty Reduction", 8.

19 USA Refugee Council, "3 Countries In The World That Produce The Largest Number Of Refugees" (Washington, D.C., 2016), https://www.google.com/search?source=hp\&ei= Y17xWtKbNontvgSH146QCw\&q=refugee + cou
ncil+USA\&oq=refugee+council+USA\&gs_l=ps y-ab.3.(Accessed 8/05/2018).

20 Seth G Jones, Andrew M Liepman, and Nathan Chandler, "Counterterrorism and Counterinsurgency in Somalia" (Santa Monica, California, 2016), www.rand.org/t/RR1539\%0 ALibrary, 9-11.

21 Priya Gajraj, Shonali Sardesai, and Per Wam, "Conflict in Somalia: Drivers and Dynamics (English)," World Bank, Washington, D.C, 2005,

http://documents.worldbank.org/curated/en/537 531468335694025/Conflict-in-Somalia-driversand-dynamics (Accessed 08/05/2018), 9-10.

${ }^{22}$ William J. Olson, "The New World Disorder: Governability and Development.," in Gray Area Phenomena: Confronting New World Disorder, ed. Max G. Manwaring, 1st ed. Boulder: Westview Press, 1993. 10-12

23 See for example, Donald W Potter, "State Responsibility , Sovereignty , and Failed States," in Australasian Political Studies Association Conference, University of Adelaide 29 September - 1 October, 2004, 1-16.

24 United Nations High Commission for Refugees, "Regional Refugee Response Plan Nigeria" Abuja, 2017, reporting.unhcr.org/node/1 6433\%0A(Accessed 08/05/2018).

25 Oxfam, "Lake Chad's Unseen Crisis" Oxford: Oxfam.org, 2016, https://www.oxfam.org/en /research/lake-chads-unseen-crisis (Accessed 23/09/2017), 2.

26 UNHCR, "Supplementary Appeal: Nigeria Situation" Geneva, 2017, http://www.unhcr.or g/en-my/partners/donors/589496b67/unhcrnigeria-situation-supplementary-appeal-januarydecember-2017-2-february.html (Accessed 2/10/2017).

27 Ibid

28 Ibid.

29 M. Jamil Hanifi, "Causes and Consequences of the Destabilization of Afghanistan," in Afghanistan, 1979-2009: In the Grip of Conflict, Viewpoints, Washington, DC: The Middle East Institute, 2009, p.23.

30 Ibid

31 William Maley, "Afghanistan: An Historical and Geographical Appraisal," (2010) 92 (880) International Review of the Red Cross, 859-76, p. $859-60$.

32 Hanifi, "Causes and Consequences of the Destabilization of Afghanistan," 25.

33 Ibid.

34 Héloïse Ruaudel, "Armed non- State Actors and Displacement in Armed Conflict",Geneva: Geneva Call, 2013, http://www.genevacall. org/wp-content/uploads/dlm_uploads/2013/12 
/Armed-non-State-actors-and-displacement-inarmed-conflict1.pdf (Accessed 11/05/2018), 8.

35 See Human Rights Watch, "Syria: Events of 2016", New York, 2017, https://www.hrw.org/ world-report/2017/country-chapters/syria (Accessed 11/05/2018).; Syrian Network for Human Rights, "The 6th Anniversary of the Breakout of the Popular Uprising towards Freedom, and the Killing of the First Civilians" United Kingdom, 2017, www.sn4hr.org (Accessed 8/6/2017).

36 Syrian Network for Human Rights, "The 6th Anniversary of the Breakout of the Popular Uprising towards Freedom, and the Killing of the First Civilians"

37 Gilsinan Kathy, "A Brief Guide to the Syrian Civil War - The Atlantic", Washington D C: Hayley Romer, 2015, http://www.thea tlantic.com/international/archive/2015/10/syrian -civil-war-guide-isis/410746/.

38 Syrian Network for Human Rights, "The 6th Anniversary of the Breakout of the Popular Uprising towards Freedom, and the Killing of the First Civilians"."

39 Ibid.

40 Antonio Cassese, International Law, 2nd ed. Oxford, Oxford University Press, 2005, p. 25.

41 Ibid. 124.

42 Reuven Young, "Defining Terrorism: The Evolution of Terrorism as a Legal Concept in International Law and Its Influence on Definitions in Domestic Legislation," (2006) 29 (1)Boston College International \& Comparative Law Review, 23-106, p. 53.

43 Nijman, "Non-State Actors and the International Rule of Law: Revisiting the 'realist Theory' of International Legal Personality, 99."

44 Young, "Defining Terrorism: The Evolution of Terrorism as a Legal Concept in International Law and Its Influence on Definitions in Domestic Legislation", 53.

45 Nijman, "Non-State Actors and the International Rule of Law: Revisiting the 'realist Theory' of International Legal Personality", 95.

46 Andrew Clapham, "The Rights and Responsibilities of Armed Non-State Actors: The Legal Landscape \& Issues Surrounding Engagement," SSRN Electronic Journal 1569636, no. February, 2010, 16. Available at SSRN: http://ssrn.com/abst ract=156963,doi:10. 2139/ssrn.1569636 (Accessed 26/10/2017),

47 James Crowford, Brownlie's Principles of Public International Law, 8th ed., Oxford: Oxford University Press, 2008, 118-9.

48 Cassese, International Law, 128.

49 Ibid. 71-2.

50 Crowford, Brownlie's Principles of Public International Law, 119.
51 Stilz, "Decolonization and Self-Determination", 2.

52 Hamid, Public International Law: A Practical Approach, 92.

53 United Nations, "Juridical Yearbook 1978, ST/LEG/SER.C/16" New York: United Nations Publications, 1981, https://unyearbook.un.org/ pdf (accessed 8/08/2017).

54 See UNGA, "Resolution 2918 of 14 November 1972, on the Question of Territories Under Portuguese Administration", New York: United Nations Official Records, UN Library, 1972, www.un.org/documents/ga/res/27/ares27.htm (Accessed 8/08/2017).

55 See UNGA, "Resolution 3295 of 3 December 1974, on the Question of Namibia" (New York: United Nations Official Records, UN Library, 1974), available at www.un.org/documents/ga/r es/29/ares29.htm (Accessed 8/08/2017).; see also the Namibia Case, ICJ Reports 1971, 16, available at www.icj-cij.org/files/case-relat ed/53/5597.pdf (accessed 8/08/2017).

Cassese, International Law, 140.

Raymond Ranjeva, "Peoples and National Liberation Movements," (1991), International Law: Achievements and Prospects, 101-12. p. 141

58 Cassese, International Law. 142

59 M Cherif Bassiouni, "Terrorism: The Persistent Dilemma of Legitimacy," in The War Crimes Research Symposium: "Terrorism on Trial" at Case Western Reserve University School of Law, Sponsored by the Frederick K. Cox International Law Centre, on Friday, Oct. 8, 2004, vol. 224 Cleveland, Ohio, 2004, 299-307, p. 299.

60 Ibid.

61 Holli Edwards, Does International Law Apply to the Islamic State? 1. Geneva Centre for Security Policy, http://www.gcsp.ch/download/6501/1 52083 (Accessed 12/10/2017), 1-11, 4."

62 See for example, Brian Dube and Proceed Manatsa, Failed State Discourse under International Law.

63 Stefan Talmon, "Recognition of the Libyan National Transitional Council," (2011) 15 (16) ASIL Insights https://www.asil.org/insights (Accessed 10/11/2017).

64 Anja P. Jakobi, Non-State Violence and Political Order: A View on Long-Term Consequences of Non-State Security Governance, 2010, 4, Peace Research Institute Frankfurt (PRIF) Working Paper, 1-11, 6.

65 Dube and Manatsa, "Failed State Discourse under International Law $\square$ : The Place , Attributes and Implications." 14.

66 See for instance, Messner and Haken, "Fragile States Index 2016."; Susan E Rice and Stewart 
Partrick, "Index of State Weakness in the Developing World" Washington D C, 2008.

\section{REFERENCES}

Bassiouni, M. C. 2002. International Terrorism: a Compilation of UN Documents 1972-2001. (M. C. Bassiouni, Ed.). New York: Transnational publishers.

BBC NEWS. 2012. Guide: Syria Crisis. Retrieved June 7, 2017, from http://www.bbc.com/news/worldmiddle-east-13855203 (accessed 07/06/2017)

Bellal, A., Giacca, G., \& Casey-Maslen, S. 2011. International law and armed non-state actors in Afghanistan. International Review of the Red Cross, 93(881), 47-79. https://doi.org/10.1017/S18163831 11000051

Brent, M. 2009. Responding to Attacks by Non-State Actors $\square$ : The Attribution Requirement of SelfDefence. Austl. Int'1 L.J., 16(October), 133-159.

Cassese, A. 2005. International Law (2nd ed.). Oxford: Oxford University Press.

Chengu, G. 2014. How The US Helped Create Al-Qaeda and ISIS. Retrieved from https:www.counterpunch.org (Accessed 10/11/2017)

Clapham, A. 2006. Human rights obligations of non-state actors. Oxford: OUP Oxford.

Clapham, A. 2010. The Rights and Responsibilities of Armed NonState Actors: The Legal Landscape \& Issues Surrounding Engagement. SSRN Electronic Journal1569636, (February), Available at SSRN: http://ssrn.com/abstract=156963. https://doi.org/10.2139/ssrn.156963 6 (Accessed 12/10/2017)

Crowford, J. 2008. Brownlie's Principles of Public International Law (8th ed.). Oxford: Oxford University Press.

Dube, B., \& Manatsa, P. 2013. Failed State Discourse under International Law $\square$ : the Place, Attributes and Implications. International Journal of Politics and Good Governance, 4(4), 1-23.

Edwards, H. 2017. Does International Law Apply to the Islamic State? Geneva Centre for Security Policy, (1), 111. Retrieved from http://www.gcsp.ch/download/6501 /152083 (Accessed 6/09/2017)

Hanifi, M. J. 2009. Causes and Consequences of the Destabilization of Afghanistan,. In Afghanistan, 1979-2009: In the Grip of Conflict (Viewpoints). Washington, DC: The Middle East Institute.

Jackson, R. H. 1998. Surrogate Sovereignty $\square$ ? Great Power Responsibility and "Failed States" (No. 25). Vancouver.

Jakobi, A. P. 2010. Non-State Violence and Political Order: A View on Long-Term Consequences of Nonstate Security Governance (No. 4). Frankfurt.

Jones, S. G., Liepman, A. M., \& Chandler, N. 2016. Counterterrorism and Counterinsurgency in Somalia. Santa Monica, California. Retrieved from

www.rand.org/t/RR1539\%0ALibra ry (Accessed 19/09/2017)

Messner, J. J., \& Haken, N. 2016. Fragile States Index 2016. Washington, D.C. Retrieved from www.fundforpeace.org (Accessed 2/8/2017)

Miakhel, S. 2009. Repeating History: Parallels between Mujahidin Tactics and Afghanistan's Current Insurgency. In Afghanistan, 19792009: In the Grip of Conflict (9th ed., p. 56). Washington, D.C: The Middle East Institute. Retrieved 
from http//www.mei.edu (Accessed 2/11/2017)

Moreno Torres, M., \& Anderson, M. 2004. Fragile states: defining difficult environments for poverty reduction. PRDE Working Paper, (1). Retrieved from http://www.ineesite.org/uploads/file s/resources/doc_1_FS

Diff_environ_for_pov_reduc.pdf (Accessed 03/07/2017)

National Geographic. 2017. Myanmar's Rohingya Are in Crisis - What You Need to Know. Retrieved November 2, 2017, from www.nationalge ographic.com/contributors/g/saragibbins.html (Accessed 2/11/2017)

Nijman, J. E. 2010. Non-state actors and the international rule of law $\square$ : Revisiting the "realist theory" of international legal personality (Research Paper Series) (Vol. 2010). Amsterdam. Retrieved from www.jur.uva.nl/acil (accessed 7/08/2017)

Olson, W. J. 1993. The New World Disorder: Governability and Development. In M. G. Manwaring (Ed.), Gray Area Phenomena: Confronting New World Disorder (1st ed.). Boulder: Westview Press.

Paust, J. J. 2010. Non-State Actor Participation in International Law and The Pretense of Exclusion. Virginia Journal of International Law, 51(4), 977.

Potter, D. W. 2004. State Responsibility, Sovereignty, and Failed States. In Australasian Political Studies Association Conference (pp. 1-16). University of Adelaide 29 September - 1 October.

Ranjeva, R. 1991. Peoples and national liberation movements. International Law: Achievements and Prospects, 101-112.
Rice, S. E., \& Partrick, S. 2008. Index of State Weakness in the Developing World. Washington D C.

Roberts, A., \& Sivakumaran, S. 2012a. Lawmaking by Nonstate Actors: Engaging Armed Groups in the Creation of International Humanitarian Law. Yale J. Int'l L., 37(1), 107-152. Retrieved from http://eprints.lse.ac.uk/42752/ (Accessed 15/09/2017)

Roberts, A., \& Sivakumaran, S. 2012b. Lawmaking by Nonstate Actors: Engaging Armed Groups in the Creation of International Humanitarian Law. Yale J. Int'1 L., 37(1), 107-152.

Rothberg, R. I. 2002. The New Nature of Nation-State Failure. The Washington Quarterly, 25(3), 8596.

Shaw, M. N. 2008. International law (6th ed.). Cambridge: Cambridge University Press.

Stilz, A. 2015. Decolonization and SelfDetermination. Social Philosophy and Policy, 32(1), 1-24. https://doi.org/10.1017/S02650525 15000059 (Accessed 07/10/2017)

Syrian Network for Human Rights. 2017. The 6th Anniversary of the Breakout of the Popular Uprising towards Freedom, and the Killing of the First Civilians". United Kingdom. Retrieved from www.sn4hr.org (Accessed 8/6/2017)

Szuhai, I. 2015. Rethinking the concept of failed state. Central European Papers, III (2), 99-110.

Talmon, S. 2011. Recognition of the Libyan National Transitional Council. ASIL Insights, 15(16). Retrieved from https://www.asil.org/insights (Accessed 10/11/2017)

Talmon, S. 2013. Recognition of Opposition Groups as the Legitimate Representative of a 
People. Chinese Journal of International Law, 12(2), 219-253. Retrieved from http://dx.doi.org/10.1093/chinesejil/ jmt014 (Accessed 23/10/2017)

UNHCR. 2017. Supplementary Appeal: Nigeria Situation.

United Nations. Charter of the United Nations 1945. San Francisco: www.un.org/en/documents.

Retrieved from www.un.org/en/charter-unitednations/ (Accessed 23/10/2017)

Weiss, T. G., Seyle, D. C., \& Coolidge, K. 2013. The Rise of Non-State Actors in Global Governance (Vol. 4). Broomfield, Colorado. Retrieved from

www.oneearthfuture.org.(Accessed 7/08/2017)

World Bank. 2005. Conflict in Somalia: Drivers and Dynamics. World Bank. Retrieved from http://siteresources.worldbank.org/I NTSOMALIA/Resources/conflictin somalia.pdf (Accessed 02/11/2017)

Young, R. 2006. Defining Terrorism: The Evolution of Terrorism as a Legal Concept in International Law and its Influence on Definitions in Domestic Legislation. Boston College International \& Comparative Law Review, 29(1), 23-106.

Zarei, M. H., \& Safari, A. 2015. The Status of Non-State Actors under the International Rule of Law: A Search for Global Justice. Rethinking International Law and Justice, 233-252.

Suleiman Usman Santuraki

Department of Public Law

Faculty of Law

University of Maiduguri

Nigeria

Email: suleisant@unimaid.edu.ng 